Revista Eletrônica de Direito Processual - REDP.

Rio de Janeiro. Ano 12. Volume 19. Número 2. Maio a Agosto de 2018

Periódico Quadrimestral da Pós-Graduação Stricto Sensu em Direito Processual da UERJ

Patrono: José Carlos Barbosa Moreira (in mem.). ISSN 1982-7636. pp. 67-83

www.redp.uerj.br

\title{
A POSSIBILIDADE DE REDUÇÃO DA MULTA COERCITIVA COM \\ FUNDAMENTO NO DUTY TO MITIGATE THE LOSS ${ }^{1}$
}

\section{THE POSSIBILITY OF REDUCTION OF THE FINE COERCIVE BASED ON DUTY TO MITIGATE THE LOSS}

Caroline Melchiades Salvadego Guimarães de Souza Lima Mestranda do Programa de Mestrado em Direito Negocial da Universidade Estadual de Londrina. Graduada em Direito pela Pontifícia Universidade Católica do Paraná - campus Londrina. E-mail: carolm_92@ hotmail.com.

Roberto Wagner Marquesi Doutor e Mestre em Direito Civil pela USP, Largo de São Francisco. Mestre em Direito pela UEL. Professor do Programa Mestrado e Pós-graduação - Lato Sensu na Universidade Estadual de Londrina - UEL. Professor Universitário na Universidade Estadual de Londrina - UEL e na Pontifícia Universidade Católica do Paraná - campus Londrina. E-mail: wagnermarquesi@uol.com.br.

RESUMO: O presente estudo tem por objetivo analisar a teoria do duty to mitigate the loss e a sua aplicação no âmbito do direito processual civil brasileiro, com especial análise acerca da multa coercitiva, utilizando-se o método dedutivo e interpretativo por meio análise doutrinária, legislativa e principalmente jurisprudencial. Consoante a referida teoria, que advém do princípio da boa-fé objetiva, o credor deve mitigar o seu próprio prejuízo, nesse aspecto, em um cenário em que o credor se mantém inerte objetivando majorar a multa, há evidente abuso de direito. Destaca-se, portanto, a necessidade de questionar qual a consequência e implicação quando comprovada tal situação e qual o posicionamento adotado pelo judiciário, exaurindo-se assim a problemática do presente artigo, justamente por se tratar de recente aplicação no ordenamento jurídico e ainda não existir um posicionamento pacífico entre os Tribunais de Justiça, contribuindo assim com estudos para melhor correlacionar os temas expostos e demonstrar a aplicabilidade do duty to mitigate the loss ao processo civil.

PALAVRAS-CHAVE: Duty to mitigate the loss. Princípios processuais. Astreintes. Boa-fé processual. Multa coercitiva.

ABSTRACT: The purpose of this study is to analyze the theory of the duty to mitigate the loss and its application in the scope of Brazilian civil procedural law, with special analysis on the coercive fine, using the deductive and interpretative method through doctrinal,

\footnotetext{
${ }^{1}$ Artigo recebido em 11/12/2017 e aprovado em 23/03/2018.
} 
Revista Eletrônica de Direito Processual - REDP.

Rio de Janeiro. Ano 12. Volume 19. Número 2. Maio a Agosto de 2018

Periódico Quadrimestral da Pós-Graduação Stricto Sensu em Direito Processual da UERJ

Patrono: José Carlos Barbosa Moreira (in mem.). ISSN 1982-7636. pp. 67-83

www.redp.uerj.br

legislative and mainly case law. According to this theory, which comes from the principle of objective good faith, the creditor must mitigate his own loss, in this respect, in a scenario where the creditor remains inert in order to increase the fine, there is an obvious abuse of rights. Therefore, it is necessary to question the consequence and implication when this situation is proven and the position adopted by the judiciary, thus exhausting the problematic of this article, precisely because it is a recent application in the legal system and not yet there is a peaceful positioning among the Courts of Justice, thus contributing with studies to better correlate the exposed topics and demonstrate the applicability of the duty to mitigate the loss to the civil process.

KEY WORDS: Duty to mitigate the loss. Principles of civil lawsuit. Astreintes. Good faith process. Coercive fine.

\section{INTRODUÇÃO}

O ordenamento jurídico pátrio constantemente aprimora-se na busca de soluções para conflitos antes inimagináveis e que apenas são enfrentados ao longo dos tempos e em razão das evidentes mudanças ocorridas na sociedade. Certo é que os operadores do direito buscam constantemente encontrar meios e alternativas para solucionar embates e divergências de entendimento.

A positivação da boa-fé objetiva e a preocupação com os deveres colaterais a ela anexos, que se evidenciou com mais força após o advento do Código Civil de 2002, tratase de um apropriado exemplo para demonstrar a preocupação do legislador em buscar solucionar questões atinentes à não observação de princípios básicos norteadores do direito privado, que se estende a outros ramos do direito, como por exemplo o direito processual civil.

No âmbito processual civil é categoricamente verificada a boa-fé processual, princípio norteador desse sistema e que justamente decorre do princípio da boa-fé objetiva. Por este princípio, em especial análise do direito processual, deve-se esperar das partes envolvidas no processo uma conduta pautada na lealdade, honestidade, cooperação e probidade, evitando ao máximo lesar o outro litigante com a prática de comportamentos em contrariedade à boa-fé, destacando a observância dos deveres parcelares tais como a supressio, venire contra factum proprium, e especialmente o duty to mitigate the loss, consoante o qual é dever do credor diligenciar para que o seu próprio prejuízo não aumente em grandes proporções, em desproporcional prejuízo ao devedor e à própria boa-fé objetiva. 
Revista Eletrônica de Direito Processual - REDP.

Rio de Janeiro. Ano 12. Volume 19. Número 2. Maio a Agosto de 2018

Periódico Quadrimestral da Pós-Graduação Stricto Sensu em Direito Processual da UERJ

Patrono: José Carlos Barbosa Moreira (in mem.). ISSN 1982-7636. pp. 67-83

www.redp.uerj.br

Nesta senda, vale observar que o credor de uma multa coercitiva deve contribuir

para o efetivo cumprimento de uma ordem judicial determinada ao devedor, mitigando assim o seu próprio prejuízo, sob pena violar o princípio da boa-fé processual. Todavia, a respeito de tal situação, verifica-se que a lei processual pátria não prevê especificamente a possibilidade de redução ou extirpação da multa coercitiva para os casos em que houver violação ao duty to mitigate the loss.

Com efeito, a problemática do presente artigo traduz-se em verificar a possibilidade ou não de aplicação da referida teoria ao processo civil pátrio e quais as suas consequências, objetivando realizar um estudo com especial destaque às multas coercitivas, verificando assim a possibilidade de redução das astreintes caso o princípio da boa-fé objetiva seja ignorado pelo credor.

A preocupação e a justificativa do presente trabalho evidencia-se justamente por se tratar de matéria recentemente aplicada no ordenamento jurídico e ainda não existir um posicionamento pacífico entre os Tribunais de Justiça, contribuindo assim com estudos para melhor correlacionar os temas expostos, utilizando-se o método dedutivo e interpretativo por meio de análise doutrinária, legislativa e principalmente jurisprudencial, perquirindo alcançar um resultado conclusivo acerca da aplicação do duty to mitigate the loss loss ao processo civil pátrio.

\section{O PRINCÍPIO DA BOA-FÉ OBJETIVA NO DIREITO PROCESSUAL CIVIL: APLICAÇÃO NO CÓDIGO DE PROCESSO CIVIL DE 2015}

O princípio da boa-fé, ou em latim bonna fides, decorre de ideias e conceitos que surgiram desde o direito Romano e ao longo das décadas vem sendo aprimorado. Destacase que naquela época, para os romanos, o termo fides tinha vigência em diversos áreas e níveis jurídicos, políticos e sociológicos, podendo ser atribuído como sinônimo de confiança, colaboração e auxílio mútuo nas relações entre iguais, e ainda como fundamento de justiça ${ }^{2}$.

Uma das pioneiras e mais importantes aparições do princípio da boa-fé no mundo jurídico se deu com a edição do Código Civil Francês em 1803, trazendo a ideia de que a

\footnotetext{
2 MARTINS-COSTA, Judith. A boa-fé no direito privado: critérios para a sua aplicação. São Paulo: Marcial Pons, 2015, p. 49.
} 
Revista Eletrônica de Direito Processual - REDP.

Rio de Janeiro. Ano 12. Volume 19. Número 2. Maio a Agosto de 2018

Periódico Quadrimestral da Pós-Graduação Stricto Sensu em Direito Processual da UERJ

Patrono: José Carlos Barbosa Moreira (in mem.). ISSN 1982-7636. pp. 67-83

www.redp.uerj.br

boa-fé sempre se presume em detrimento da má-fé, esta última devendo ser comprovada por quem alega, como destaca Rosa Maria de Andrade Nery ${ }^{3}$. Não obstante, vale dizer que o princípio e o próprio conceito da boa-fé influenciaram diversos ordenamentos jurídicos inclusive o brasileiro.

No ordenamento jurídico pátrio, infere-se que o "primeiro dispositivo legal a prever a boa-fé no direito brasileiro foi o art. 131, inciso I, do Código Comercial de 1850 [...] A doutrina, entretanto, entendeu que a boa-fé nele aludida era subjetiva"^4 e, portanto, não houve muito aplicação pelos tribunais. Destaca-se, no entanto, que a mais forte aparição do princípio da boa-fé objetiva se deu com o advento do Código de Defesa do Consumidor em 1990, consagrando a boa-fé objetiva como forma de interpretação das relações consumeristas. Mais adiante, com a promulgação do Código Civil de 2002, o princípio da boa-fé objetiva ganhou maior importância no ordenamento jurídico pátrio, tornando-se fonte de direitos e obrigações para as relações jurídicas, especialmente diante de uma relação contratual.

Vale destacar que não só no campo contratual a boa-fé está expressamente presente no Código Civil de 2002, isso porque ela também ganha evidente repercussão no artigo 187 do mesmo diploma citado, elevando o princípio da boa-fé objetiva a um parâmetro de licitude/ilicitude. Nesse aspecto, vale transcrever as palavras de Teresa Negreiros ao comentar o celebrado princípio da boa-fé ${ }^{5}$.

\begin{abstract}
A repercussão do princípio da boa-fé ganha ainda maior impacto em vista do disposto no igualmente famoso art. 187 do código Civil de 2002. A boa-fé, ali, é elevada a parâmetro de licitude/ilicitude do exercício dos direitos em geral (e não apenas das disposições contratuais), de tal modo que, nas palavras da lei, "Também comete ato ilícito o titular de um direito que, ao exerce-lo excede manifestamente os limites impostos pelo seu fim econômico ou social, pela boafé ou pelos bons costumes.
\end{abstract}

Verifica-se que a boa-fé, propriamente dita, possui duas vertentes, classificandose em subjetiva e objetiva. Em seu sentido subjetivo deve-se buscar analisar a vontade interna da pessoa, suas crenças e ideais, trata-se da verdadeira intenção do agente de querer

\footnotetext{
${ }^{3}$ NERY, Rosa Maria de Andrade. Instituições de direito Civil, volume I, tomo I: teoria geral do direito privado. São Paulo: Revista dos Tribunais, 2014, p. 570.

${ }^{4}$ GOMES, Orlando. Contratos. Rio de Janeiro, Forense, 2009, p. 44.

${ }^{5}$ NEGREIROS, Teresa. O princípio da boa-fé contratual. In: BODIN DE MORAES, Maria Celina (Org.). Princípios do direito civil contemporâneo. Rio de Janeiro: Renovar, 2006. p. 223.
} 
Revista Eletrônica de Direito Processual - REDP.

Rio de Janeiro. Ano 12. Volume 19. Número 2. Maio a Agosto de 2018

Periódico Quadrimestral da Pós-Graduação Stricto Sensu em Direito Processual da UERJ

Patrono: José Carlos Barbosa Moreira (in mem.). ISSN 1982-7636. pp. 67-83

www.redp.uerj.br

ou não lesar um terceiro, devendo nestes casos o juiz analisar o estado de ignorância ou ciência da pessoa em violar o direito de outrem ${ }^{6}$.

Já a boa-fé objetiva, caracteriza-se como regras de condutas, dimensionando comportamentos a serem seguidos por todos, com fundamento na confiança, cooperação, honestidade e lealdade das partes envolvidas, são verdadeiros padrões a serem seguidos pelas partes, dos quais independem do juízo de valor acerca da verdadeira intenção da pessoa em determinada situação.

Ainda que a aplicação deste importante princípio seja mais evidente no âmbito do direito material, ressalta-se que ele também pode ser observado no âmbito do direto processual civil, notadamente como um princípio norteador. Nos ensinamentos de Humberto Theodoro Junior, ainda sob a égide do Código de Processo Civil de 1973, o Estado e as partes devem conjugar esforços no processo para solucionar o litígio ${ }^{7}$, sendo assim, nas relações processuais há evidente e relevante interesse público, daí a necessidade de as leis adotarem procedimentos sob o princípio da boa-fé e lealdade das partes e do próprio Juiz, é o que se verificava no artigo 14, inciso II $^{8}$ daquele diploma, hoje já revogado.

No caminho da constitucionalização do direito civil, sobretudo em razão da influência da Constituição Federal de 1988, que consagrou fundamentos republicanos, sobretudo com fins a respeitar a dignidade da pessoa humana em todos os âmbitos do ordenamento jurídico, destaca-se que o Código de Processo Civil de 2015 veio afirmar o processo civil constitucionalizado, especialmente por inserir dispositivos que visam a ponderação e observação de princípios e cláusulas gerais para resolução dos mais relevantes conflitos 9 .

Nesta senda, com o advento do Código de Processo Civil de 2015, o princípio da boa-fé encontra-se ainda mais evidenciado, estando expressamente previsto em pelo menos

\footnotetext{
${ }^{6}$ VENOSA, Sílvio de Salvo. Direito civil: teoria geral das obrigações e teoria geral dos contratos - 13. ed. São Paulo: Atlas, 2013. p, 396

${ }^{7}$ THEODORO JUNIOR, Humberto. Curso de direito Processual Civil. Rio de Janeiro. Forense, 2005, p. 26.

${ }^{8}$ Neste sentido é a redação do Art. 14, inciso II: São deveres das partes e de todos aqueles que de qualquer forma participam do processo: [...] II - proceder com lealdade e boa-fé;

${ }^{9}$ BODIN DE MORAES, Maria Celina; BARBOSA, Fernanda Nunes. O processo civil constitucionalizado. Editorial à Civilistica.com. Rio de Janeiro, a. 5, n. 1, 2016. Disponível em: <http://civilistica.com/o-processocivil-constitucionalizado/>. Data de acesso 07/11/2017.
} 
Revista Eletrônica de Direito Processual - REDP.

Rio de Janeiro. Ano 12. Volume 19. Número 2. Maio a Agosto de 2018

Periódico Quadrimestral da Pós-Graduação Stricto Sensu em Direito Processual da UERJ

Patrono: José Carlos Barbosa Moreira (in mem.). ISSN 1982-7636. pp. 67-83

www.redp.uerj.br

três dispositivos distintos, quais sejam, o artigo $5^{\text {ol0 }}$, trazendo a ideia de que todos que participam do processo devem agir em boa-fé, o artigo $322, \S 2^{011}$, no qual está expresso que o pedido deverá ser interpretado pela boa-fé e o artigo $489, \S 3^{\circ 12}$ em que fica clara a necessidade da decisão judicial ser interpretada em conformidade com o princípio da boafé.

A esse respeito, importante destacar a lição de Araken de Assis, no sentido de que o processo "não é instrumento neutro, mas atividade entroncada nos mais altos valores da sociedade: probidade, lealdade, boa-fé" ${ }^{13}$ reforçando a concepção de que o princípio da boa-fé objetiva deve estar presente no âmbito processual civil e nas condutas realizadas pelos litigantes.

\section{OS DIREITOS E DEVERES ACESSÓRIOS DECORRENTES DA BOA-FÉ OBJETIVA APLICADOS AO PROCESSO CIVIL BRASILEIRO}

Conforme acima exposto, aplicam-se à Teoria Geral do Processo o princípio da boa-fé objetiva, os seus deveres anexos, entre eles os deveres de respeito, transparência, lealdade, razoabilidade, informação, cooperação, honestidade, confiança, e igualmente os seus conceitos parcelares, tais como a supressio venire contra factum proprium e duty to mitigate the loss, sendo todos de total importância.

A esse respeito, vale transcrever os ensinamentos de José Miguel Garcia Medina quanto à aplicação do conceito de venire contra factum proprium no âmbito do processo civil brasileiro.

Dentre as consequências da proteção à boa-fé objetiva, no âmbito processual, não se aceita que parte adote comportamento contraditório. Pró́be-se, assim, venire contra factum proprium, ou seja, não se permite que o comportamento gerador de expectativa justificada seja posteriormente contrariado, em detrimento de outrem. É que, agindo desse modo, a parte viola o princípio da confiança no tráfego jurídico, já que, uma vez despertada a legítima confiança, espera-se um comportamento em sintonia com o procedimento até então

\footnotetext{
${ }^{10}$ Nesse sentido é a redação do At. 5, $\mathrm{CPC} / 2105$ : Aquele que de qualquer forma participa do processo deve comportar-se de acordo com a boa-fé.

${ }^{11}$ Neste sentido é a redação do Art. $322 \S 2^{\circ}, \mathrm{CPC} / 2015$ : A interpretação do pedido considerará o conjunto da postulação e observará o princípio da boa-fé.

${ }^{12}$ Neste sentido é a redação do Art. $489 \S 3^{\circ}, \mathrm{CPC} / 2015$ A decisão judicial deve ser interpretada a partir da conjugação de todos os seus elementos e em conformidade com o princípio da boa-fé.

13 ASSIS, Araken. Processo civil brasileiro, volume I [livro eletrônico]: parte geral: fundamentos e distribuição de conflitos - 1 ed. São Paulo: Revista dos Tribunais, 2015.
} 
Revista Eletrônica de Direito Processual - REDP.

Rio de Janeiro. Ano 12. Volume 19. Número 2. Maio a Agosto de 2018

Periódico Quadrimestral da Pós-Graduação Stricto Sensu em Direito Processual da UERJ

Patrono: José Carlos Barbosa Moreira (in mem.). ISSN 1982-7636. pp. 67-83

www.redp.uerj.br

manifestado ${ }^{14}$.

Aliás, tanto no antigo quanto no Código de Processo Civil de 2015 pode-se observar que referido princípio da venire já se encontra até mesmo positivado na estrutura jurídica brasileira, a exemplo do artigo 17 , inciso I do CPC/1973 ${ }^{15}$, reproduzido no artigo 80, inciso I do $\mathrm{CPC} / 2015^{16}$.

A respeito do assunto, Anderson Schreiber faz uma excelente observação com relação a aplicação da proibição do comportamento contraditório:

\begin{abstract}
Mais que isso: a proibição de comportamento contraditório, por ser instituto ancorado na tutela da confiança, transcende as meras situações de contradição lógica no processo. Mesmo que não haja contradição lógica, pode haver contradição axiológica. Em outras palavras: condutas que não sejam logicamente contraditórias podem se revelar contraditórias no plano valorativo, uma vez que sejam capazes de ferir a legítima confiança despertada na outra parte. Enquanto o processo civil tradicional reprime apenas as contradições mais flagrantes (por meio da preclusão lógica e outros institutos), a aplicação da boa-fé objetiva vem permitir a repressão de outras espécies de contradições, menos sutis ou que abarquem comportamentos adotados extraprocessualmente ${ }^{17}$.
\end{abstract}

A título exemplificativo, o Superior Tribunal de Justiça já vem consagrando em suas decisões a proibição do venire contra factum proprium, conforme recente julgado daquela Corte Superior, cuja relatoria coube ao Excelentíssimo Ministro Mauro Campbell Marques, de numeração REsp 1505999/PR, em que fica clara a aplicabilidade de tal conceito parcelar do princípio da boa-fé objetiva, especificamente para afastar uma conduta contraditória da parte litigante ${ }^{18}$.

De outro lado, pode-se observar também no âmbito do direito processual civil o instituto da supressio, segundo o qual a parte que deixar de exercer um direito por longo

\footnotetext{
14 MEDINA, José Miguel Garcia. Novo Código de Processo Civil Comentado: com remissões e notas comparativas ao CPC/1973 - 4ed. São Paulo: Revista dos Tribunais, 2016, p. 52.

${ }^{15}$ Neste sentido é a redação do Art. 17. Reputa-se litigante de má-fé aquele que: I - deduzir pretensão ou defesa contra texto expresso de lei ou fato incontroverso;

${ }^{16}$ Neste sentido é a redação do Art. 80. Considera-se litigante de má-fé aquele que: I - deduzir pretensão ou defesa contra texto expresso de lei ou fato incontroverso;

${ }^{17}$ SCHREIBER, Anderson, A proibição de comportamento contraditório: tutela da confiança e venire contra factum proprium. - 4. ed. revista e atualizada - São Paulo: Atlas, 2016, p. 153.

18 Nesse sentido convém destacar trecho da ementa do caso em comento: “[...] 2. Havendo anterior manifestação da parte com indicação de prevenção do relator e proferida decisão que lhe foi desfavorável, a pretensão da parte de modificar novamente a relatoria do recurso, com pedido de retorno ao relator anteriormente atribuído, beira a violação o princípio da boa-fé, incidindo na proibição do venire contra factum proprium. [...] (AgInt no REsp 1505999/PR, Rel. Ministro MAURO CAMPBELL MARQUES, SEGUNDA TURMA, julgado em 02/05/2017, DJe 05/05/2017)"
} 
Revista Eletrônica de Direito Processual - REDP.

Rio de Janeiro. Ano 12. Volume 19. Número 2. Maio a Agosto de 2018

Periódico Quadrimestral da Pós-Graduação Stricto Sensu em Direito Processual da UERJ

Patrono: José Carlos Barbosa Moreira (in mem.). ISSN 1982-7636. pp. 67-83

www.redp.uerj.br

período de tempo, gera à outra parte expectativa de que não irá mais exercê-lo, implicando no desaparecimento do próprio direito.

O Superior Tribunal de Justiça, em julgado recente, houve por bem em aplicar o instituto em situação concreta de inércia do credor, por longo período de tempo, reconhecendo o desaparecimento do direito que havia sido pleiteado ${ }^{19}$.

Ainda com relação aos deveres implícitos da boa-fé, evidencia-se a teoria do duty to mitigate the loss, a qual, nas palavras de Vera Maria Jacob de Fradera, tem origem no Direito anglo-saxão, e constitui-se no dever do credor diligenciar para que o seu prejuízo não aumente consideravelmente, porquanto, caso se mantenha inerte na intenção de multiplicar o prejuízo, caracterizar-se-á em verdadeiro abuso de direito, ocasionando a violação do princípio da boa-fé objetiva e dos deveres de cooperação e lealdade.

O preceito acima indicado enfrenta variações em conformidade com os ordenamentos jurídicos, se fazendo presente por exemplo, no art. 77 da Convenção de Viena de $1980^{20}$, bem assim, no âmbito do direito brasileiro, se faz exposto no Enunciado n 169 da III Jornada de Direito Civil do Conselho da Justiça Federal, cuja redação ensina que o "Princípio da boa-fé objetiva deve levar o credor a evitar o agravamento do próprio prejuízo", valendo destacar que o referido enunciado foi fundamentado pela mencionada jurista, valendo transcrever suas palavras:

O dever de mitigar, atribuído ao credor - mitigate -, tem origem no Direito

\footnotetext{
${ }^{19}$ Nesse sentido transcreve-se um trecho do julgado em comento: “[...] 2. Todavia, no caso, os credores levantaram o montante da condenação, conforme calculado pelo auxiliar do Juízo, sem suscitar a questão de juros de mora e correção monetária entre o cálculo e o levantamento - agitada nos autos mais de um ano depois. Com efeito, é patente a preclusão, inclusive para o Juízo, que, em vista da proteção à boa-fé objetiva e à segurança jurídica, não pode, a destempo, examinar questão que os credores, devidamente representados por advogados, não suscitaram oportunamente. 3. A tese recursal acerca da irrazoabilidade do pleito se coaduna com o princípio da boa-fé objetiva, que coíbe omissões prolongadas no tempo, que suscitam no devedor a legítima expectativa de que não sofreria mais nenhuma cobrança, a configurar a supressio. 4. Por um lado, a supressio inibe o exercício de um direito, até então reconhecido, pelo seu não exercício. Por outro lado, e em direção oposta à supressio, mas com ela intimamente ligada, tem-se a teoria da surrectio, cujo desdobramento é a aquisição de um direito pelo decurso do tempo, pela expectativa legitimamente despertada por ação ou comportamento. Enunciados 412 e 414 da V Jornada de Direito Civil do CJF. 5. A ideia de ônus consiste em que a parte deve, no processo, praticar oportunamente determinados atos em seu próprio benefício; consequentemente, se ficar inerte, esse comportamento poderá acarretar efeito danoso para ela, conforme inteligência do disposto no art. 183, caput, do CPC de 1973. [...] (REsp 1426413/RJ, Rel. Ministro LUIS FELIPE SALOMÃO, QUARTA TURMA, julgado em 01/12/2016, DJe 22/02/2017)"

${ }^{20}$ A parte que invocar o inadimplemento do contrato deverá tomar as medidas que forem razoáveis, de acordo com as circunstâncias, para diminuir os prejuízos resultantes do descumprimento, incluídos os lucros cessantes. Caso não adote estas medidas, a outra parte poderá pedir redução na indenização das perdas e danos, no montante da perda que deveria ter sido mitigada.
} 
Revista Eletrônica de Direito Processual - REDP.

Rio de Janeiro. Ano 12. Volume 19. Número 2. Maio a Agosto de 2018

Periódico Quadrimestral da Pós-Graduação Stricto Sensu em Direito Processual da UERJ

Patrono: José Carlos Barbosa Moreira (in mem.). ISSN 1982-7636. pp. 67-83

www.redp.uerj.br

anglo-saxão, de onde passou para os sistemas jurídicos continentais. O vocábulo "mitigate" tem raiz francesa, provém do verbo mitiger. A recepção desse conceito deu-se de maneira desigual e assistemática, pois alguns ordenamentos o utilizam freqUentemente, como é o caso do alemão e do suíço; outros, nem tanto, havendo, ainda, aqueles que dele se servem sem dar-lhe essa denominação, como é o caso do ordenamento francês $[\ldots]^{21}$

E continua a mesma ideia no sentido de que:

No sistema do Código Civil brasileiro de 2002, de acordo com o disposto no art. 42226, o duty to mitigate the loss poderia ser considerado um dever acessório, derivado do princípio da boa-fé objetiva, pois nosso legislador, com apoio na doutrina anterior ao atual Código, adota uma concepção cooperativa de contrato. $^{22}$

Para convalidar os ensinamentos de Vera Maria Jacob de Fradera, vale destacar as palavras do doutrinador Flavio Tartuce ao explicar o conceito do duty to mitigate the loss:

A proposta, elaborada por Vera Maria Jacob de Fradera, professora da Universidade Federal do Rio Grande do Sul, representa muito bem a natureza do dever de colaboração, presente em todas as fases contratuais e que decorre do princípio da boa-fé objetiva e daquilo que consta do art. 422 do CC. Anote-se que o Enunciado n. 169 do CJF/STJ está inspirado no art. 77 da Convenção de Viena de 1980, sobre a venda internacional de mercadorias, no sentido de que "A parte que invoca a quebra do contrato deve tomar as medidas razoáveis, levando em consideração as circunstâncias, para limitar a perda, nela compreendido o prejuízo resultante da quebra. Se ela negligencia em tomar tais medidas, a parte faltosa pode pedir a redução das perdas e danos, em proporção igual ao montante da perda que poderia ter sido diminuída". Para a autora da proposta, há uma relação direta com o princípio da boa-fé objetiva, uma vez que a mitigação do próprio prejuízo constituiria um dever de natureza acessória, um dever anexo, derivado da boa conduta que deve existir entre os negociantes ${ }^{23}$.

A partir dos conceitos acima expostos, infere-se que as partes envolvidas em uma relação jurídica devem tomar o máximo de precauções para que não agrave o dano já sentido. Ainda que seja incomum considerar que o credor tem a obrigação de mitigar o seu próprio prejuízo, é importante destacar que tal conduta possui estreita relação com o princípio da boa-fé. Em outras palavras, existindo uma obrigação, seja de qual natureza for, o objetivo do credor traduz-se em ver o seu cumprimento e satisfação, nesse sentido, é

\footnotetext{
${ }^{21}$ FRADERA, Vera Maria Jacob de. Justificativa a proposta de Enunciado: O credor poderá ser instado a mitigar o próprio prejuízo (art. 422). In: III Jornada de Direito Civil. Organização Ministro Ruy Rosado de Aguiar Júnior. Brasília: Conselho da Justiça Federal, Centro de Estudos Jurídicos, 2005, p. 171.

${ }^{22}$ FRADERA, Vera Maria Jacob de. Justificativa a proposta de Enunciado: O credor poderá ser instado a mitigar o próprio prejuízo (art. 422). In: III Jornada de Direito Civil. Organização Ministro Ruy Rosado de Aguiar Júnior. Brasília: Conselho da Justiça Federal, Centro de Estudos Jurídicos, 2005, p. 175.

${ }^{23}$ TARTUCE, Flávio. Manual de direito civil: volume único. 6. ed. rev., atual. e ampl. - Rio de Janeiro: Forense; São Paulo: MÉTODO, 2016, p. 639.
} 
Revista Eletrônica de Direito Processual - REDP.

Rio de Janeiro. Ano 12. Volume 19. Número 2. Maio a Agosto de 2018

Periódico Quadrimestral da Pós-Graduação Stricto Sensu em Direito Processual da UERJ

Patrono: José Carlos Barbosa Moreira (in mem.). ISSN 1982-7636. pp. 67-83

www.redp.uerj.br

sua obrigação certificar se alguma conduta sua pode ser determinante para reduzir os

danos, caso contrário, em razão da sua inércia ou conduta proposital para majoração dos danos estar-se-á diante de um abuso de direito por parte do credor, isto porque, quanto maior o dano resultante do inadimplemento maior o distanciamento do resultado pretendido, desvirtuando assim o propósito a ser alcançado, que é o adimplemento.

\section{DA MULTA COERCITIVA NO PROCESSO CIVIL BRASILEIRO: ASPECTOS RELEVANTES DENTRO DO CONTEXTO}

Delineada a questão da boa-fé processual, insta destacar que por muito tempo permaneceu em no ordenamento jurídico pátrio a ideia de que não havia meios de obrigar o sujeito a adimplir uma obrigação e imposição judicial.

O próprio Código de Processo Civil de 1973 foi constituído a partir de regras processuais que não permitiam o alcance da tutela especifica. Contudo, após relevante reforma processual com a edição da Lei $\mathrm{n}^{\circ}$ 8.952, de 13.12.1994, foi dada nova redação ao artigo 461 daquele diploma ${ }^{24}$, conferindo ao Juiz autonomia para impor multas coercitivas, especialmente em razão do parágrafo quarto ${ }^{25}$, viabilizando assim alcançar o cumprimento da ordem judicial.

A esse respeito, vale transcrever os ensinamentos de Luiz Guilherme Marinoni em sua obra sobre o Código de Processo Civil de 2015:

Isso significa que a ação, em razão das técnicas processuais inidôneas que estavam presentes no CPC de 1973 até a reforma processual de 1994, não era capaz de permitir a obtenção da tutela inibitória, que é a mais importante de todas as tutelas específicas, pois necessária para manter incólume e íntegro o direito (como o direito da personalidade), evitando a sua degradação em pecúnia $^{26}$.

No Código de Processo Civil de 2015, a referida norma encontra

\footnotetext{
${ }^{24}$ Neste sentido é a redação do Art. 461. Na ação que tenha por objeto o cumprimento de obrigação de fazer ou não fazer, o juiz concederá a tutela específica da obrigação ou, se procedente o pedido, determinará providências que assegurem o resultado prático equivalente ao do adimplemento.

${ }^{25}$ Neste sentido é a redação do Art. $461 \S 4$ o O juiz poderá, na hipótese do parágrafo anterior ou na sentença, impor multa diária ao réu, independentemente de pedido do autor, se for suficiente ou compatível com a obrigação, fixando-lhe prazo razoável para o cumprimento do preceito.

${ }^{26}$ MARINONI, Luiz Guilherme. Novo curso de processo civil: teoria do processo civil, volume I. São Paulo: Revista dos Tribunais, 2015, p. 276.
} 
Revista Eletrônica de Direito Processual - REDP.

Rio de Janeiro. Ano 12. Volume 19. Número 2. Maio a Agosto de 2018

Periódico Quadrimestral da Pós-Graduação Stricto Sensu em Direito Processual da UERJ

Patrono: José Carlos Barbosa Moreira (in mem.). ISSN 1982-7636. pp. 67-83

www.redp.uerj.br

correspondência no artigo $536^{27}$ que traz disposições acerca do cumprimento sentença,

todavia a sua redação antiga foi praticamente reproduzida no artigo $497^{28}$, artigos esses que se complementam, ganhando maior aclaração também em seus parágrafos e artigos seguintes, destacando-se outras normas esparsas, como por exemplo o artigo 139, inciso $\mathrm{IV}^{29}$, sem correspondentes no antigo Código de Processo Civil, o qual garante ao Juiz a incumbência de determinar medidas coercitivas para determinar o cumprimento da ordem judicial, demonstrando assim a intenção do legislador em melhor disciplinar referida tutela especifica para buscar o efetivo cumprimento da decisão judicial.

A essas multas coercitivas dá-se o nome de astreintes, palavra de origem francesa que se difundiu no ordenamento jurídico brasileiro trazendo a concepção de uma penalidade para o não cumprimento da ordem judicial, podendo ser aplicada em qualquer fase do processo e se revertendo ao credor da obrigação, destacando a lição de José Miguel Garcia Medina a respeito da titularidade da multa coercitiva, situações inclusive já expressa no artigo $537 \S 2^{\circ 30}$ do Código de Processo Civil de 2015:

II. Titularidade da multa coercitiva. Dispõe o $\S 2 .^{\circ}$ do art. 537 do CPC/2015 que a multa será devida ao exequente. Nesse sentido já vinha se manifestando a jurisprudência, na vigência do CPC/1973, distinguindo a multa coercitiva da punitiva (cf. supra): "A multa processual prevista no caput do art. 14 do CPC [de 1973, correspondente ao art. 77 do CPC/2015] difere da multa cominatória prevista no art. 461, § 4..$^{\circ}$ e $5 .^{\circ}$ [do CPC/1973, correspondente ao art. 537 do $\mathrm{CPC} / 2015]$, vez que a primeira tem natureza punitiva, enquanto a segunda tem natureza coercitiva a fim de compelir o devedor a realizar a prestação determinada pela ordem judicial. Os valores da multa cominatória não revertem para a Fazenda Pública, mas para o credor, que faz jus independente do recebimento das perdas e danos" (STJ, REsp 770.753/ RS, 1. ${ }^{\text {a }}$ T., j. 27.02.2007, rel. Min. Luiz Fux). Decidiu-se, sob esse prisma, que a multa prevista no art. 461 do CPC/1973, correspondente ao art. 537 do CPC/2015, deve ser destinada ao autor da ação, e não ao Estado (STJ, REsp 949.509/RS, rel. p/ acórdão Min. Marco Buzzi, j. 08.05.2012) ${ }^{31}$

\footnotetext{
${ }^{27}$ Neste sentido é a redação do Art. 536. No cumprimento de sentença que reconheça a exigibilidade de obrigação de fazer ou de não fazer, o juiz poderá, de ofício ou a requerimento, para a efetivação da tutela específica ou a obtenção de tutela pelo resultado prático equivalente, determinar as medidas necessárias à satisfação do exequente.

${ }^{28}$ Neste sentido é a redação do Art. 497. Na ação que tenha por objeto a prestação de fazer ou de não fazer, o juiz, se procedente o pedido, concederá a tutela específica ou determinará providências que assegurem a obtenção de tutela pelo resultado prático equivalente.

${ }^{29}$ Neste sentido é a redação do Art. 139. O juiz dirigirá o processo conforme as disposições deste Código, incumbindo-lhe: [...] IV - determinar todas as medidas indutivas, coercitivas, mandamentais ou subrogatórias necessárias para assegurar o cumprimento de ordem judicial, inclusive nas ações que tenham por objeto prestação pecuniária;

${ }^{30}$ Neste sentido é a redação do Art. 537 § 20 O valor da multa será devido ao exequente.

31 MEDINA, José Miguel Garcia. Novo Código de Processo Civil Comentado: com remissões e notas comparativas ao CPC/1973 - 4ed. São Paulo: Revista dos Tribunais, 2016, p. 902.
} 
Revista Eletrônica de Direito Processual - REDP.

Rio de Janeiro. Ano 12. Volume 19. Número 2. Maio a Agosto de 2018

Periódico Quadrimestral da Pós-Graduação Stricto Sensu em Direito Processual da UERJ

Patrono: José Carlos Barbosa Moreira (in mem.). ISSN 1982-7636. pp. 67-83

www.redp.uerj.br

Dentro desta perspectiva, importante ressaltar que muitos credores, atuando de forma contrária à boa-fé, buscam dificultar ou até mesmo evitar o cumprimento da obrigação justamente para que seja maior o valor da multa.

Vale dizer, embora a referida multa seja aplicada para compelir o devedor a realizar o cumprimento de uma determinada obrigação, almejando do obrigado um comportamento de cooperação e colaboração, é preciso destacar que, também é dever do credor uma atuação em conformidade com a boa-fé, esforçando-se para evitar que o seu prejuízo se agrave. Conquanto não seja uma regra, é corrente observar uma situação em que o credor, intencionalmente, mantém-se inerte, com o único objetivo de aumentar o valor da respectiva multa coercitiva.

A partir de situações como esta acima narrada, é que se faz necessária uma resposta eficiente do Poder Judiciário para coibir condutas desonestas praticadas pelos litigantes em total contrariedade ao princípio da boa-fé.

\section{A POSSIbILIDAde DE REDUÇÃO dA MULTA COERCITIVA PELA APLICAÇÃO DO DUTY TO MITIGATE THE LOSS}

No cenário acima exposto, em que o credor objetiva majorar a sua multa utilizando-se de meios ardilosos, como, por exemplo, dificultar ou até mesmo impedir o cumprimento da obrigação pelo devedor, é necessário que o poder judiciário não se mantenha inerte a essas situações e rechace referida prática em total contradição ao princípio da boa-fé processual, de aplicação cogente a todos os litigantes.

A título exemplificativo, observa-se uma conduta de inércia do credor quando o poder judiciário impõe uma multa diária para determinada empresa não inserir o nome de alguém em órgãos de proteção ao crédito, que, por sua vez, após receber a devida intimação, não cumpre a ordem judicial e o nome é negativado. A parte credora, porém, não informa de imediato tal situação ao Juízo, justamente com a intenção de aumentar o valor da multa aplicada, vindo a informar a situação após meses da inscrição, quando o valor já está em quantia exorbitante. Nesse caso, era razoável que o prejuízo do litigante (inscrição indevida) fosse mitigado com a simples informação de descumprimento da ordem judicial e requerimento para que fosse expedido novo ofício para empresa ou 
Revista Eletrônica de Direito Processual - REDP.

Rio de Janeiro. Ano 12. Volume 19. Número 2. Maio a Agosto de 2018

Periódico Quadrimestral da Pós-Graduação Stricto Sensu em Direito Processual da UERJ

Patrono: José Carlos Barbosa Moreira (in mem.). ISSN 1982-7636. pp. 67-83

www.redp.uerj.br

ofício encaminhado diretamente para o órgão de proteção ao crédito.

Verifica-se também um exemplo, no caso em que o Juiz determina a entrega de um especifico documento, fixando uma multa coercitiva para o caso de não ser realizado o cumprimento da obrigação, no entanto, em razão de certa dificuldade para obter o documento, o devedor demora para cumprir a determinação judicial. O credor da obrigação por sua vez, conhecedor de que tal documento pode ser obtido por outros meios, sendo necessário apenas realizar requerimento em processo, não os informa ao Juízo, acabando por não cooperar com o deslinde do processo, deixando que a multa coercitiva seja majorada, e, por assim dizer, multiplicada, sem, contudo, ver satisfeita a sua pretensão principal, o seu verdadeiro objetivo, que no caso em discussão é a própria entrega do documento pretendido.

Certamente para proibir o enriquecimento ilícito, o legislador se preocupou em editar o artigo $537 \S 1^{\text {o32 }}$ do Código de Processo Civil de 2015, autorizando o juiz, de ofício ou a requerimento da parte, modificar o valor da multa ou até mesmo exclui-la em duas situações, quais seja, se tornou insuficiente ou excessiva, ou se o obrigado demonstrou cumprimento parcial superveniente da obrigação ou justa causa para o descumprimento.

Ocorre que o referido artigo não traz todas as hipóteses para a redução a multa coercitiva, isso porque nos exemplos trazidos seria perfeitamente possível a aplicação do princípio da duty to mitigate the loss como forma de justificar a redução do valor da multa.

Em outras palavras, se comprovado que o credor tinha meios de mitigar o seu prejuízo, e assim evitar maiores danos ao devedor, é perfeitamente possível a redução do valor da multa, considerando a sua conduta contrária a boa-fé processual, em verdadeiro abuso de direito e não cooperação com a parte e o próprio processo.

Vale dizer, não pode ser permitido que a parte credora, de forma intencional, se mantenha inerte para alcançar valores estratosféricos a título de multa coercitiva, porquanto tal hipótese beira o verdadeiro abuso de direito, traduzindo-se em

\footnotetext{
${ }^{32}$ Neste sentido é a redação do Art. 537. A multa independe de requerimento da parte e poderá ser aplicada na fase de conhecimento, em tutela provisória ou na sentença, ou na fase de execução, desde que seja suficiente e compatível com a obrigação e que se determine prazo razoável para cumprimento do preceito. § 1o O juiz poderá, de ofício ou a requerimento, modificar o valor ou a periodicidade da multa vincenda ou excluí-la, caso verifique que: I - se tornou insuficiente ou excessiva; II - o obrigado demonstrou cumprimento parcial superveniente da obrigação ou justa causa para o descumprimento.
} 
Revista Eletrônica de Direito Processual - REDP.

Rio de Janeiro. Ano 12. Volume 19. Número 2. Maio a Agosto de 2018

Periódico Quadrimestral da Pós-Graduação Stricto Sensu em Direito Processual da UERJ

Patrono: José Carlos Barbosa Moreira (in mem.). ISSN 1982-7636. pp. 67-83

www.redp.uerj.br

enriquecimento ilícito, devendo ser afastado pelo poder judiciário.

A esse respeito, com o objetivo de rechaçar o abuso de direito e a violação ao princípio da boa-fé objetiva, a jurisprudência do Superior Tribunal de Justiça vem entendendo ser possível a redução do valor da multa coercitiva com fundamento na teoria do duty to mitigate the loss. Nesse sentido, dois recentes julgados desta Superior Corte de Justiça:

\begin{abstract}
AGRAVO INTERNO NO RECURSO ESPECIAL. EXECUÇÃO DE MULTA COMINATÓRIA. DESCUMPRIMENTO DE OBRIGAÇÃO DE FAZER. ORDEM DE RETIRADA DO NOME DO DEVEDOR DE CADASTRO DE INADIMPLENTE. 1 . O arbitramento da multa coercitiva e a definição de sua exigibilidade, bem como eventuais alterações do seu valor e/ou periodicidade, exige do magistrado, sempre dependendo das circunstâncias do caso concreto, ter como norte alguns parâmetros: [...] Assim, levando-se em consideração a recalcitrância do devedor e, por outro lado, a possibilidade de o credor ter mitigado o prejuízo, assim como poderia o próprio juízo ter adotado outros meios suficientes para o cumprimento da obrigação, a fixação das astreintes em $\mathrm{R} \$ 5.000,00$ (cinco mil reais) atende aos critérios de razoabilidade e proporcionalidade. $[\ldots]^{33}$
\end{abstract}

RECURSO ESPECIAL. DIREITO CIVIL. OBRIGAÇÃO DE FAZER E INDENIZATÓRIA. ORDEM JUDICIAL DETERMINANDO QUE A RÉ RETIRE GRAVAMES DE VEÍCULO NO DETRAN, SOB PENA DE MULTA DIÁRIA. ASTREINTES. PARÂMETROS DE FIXAÇÃO. [...] 5. No tocante ao credor, em razão da boa-fé objetiva (NCPC, arts. $5^{\circ}$ e $6^{\circ}$ ) e do corolário da vedação ao abuso do direito, deve ele tentar mitigar a sua própria perda, não podendo se manter simplesmente inerte em razão do descaso do devedor, tendo dever de cooperação com o juízo e com a outra parte, seja indicando outros meios de adimplemento, seja não dificultando a prestação do devedor, impedindo o crescimento exorbitante da multa, sob pena de perder sua posição de vantagem em decorrência da supressio. Nesse sentido, Enunciado n ${ }^{\circ} 169$ das Jornadas de Direito Civil do CJF. [...] Levando-se em consideração, ainda, a recalcitrância do devedor e, por outro lado, a possibilidade de o credor ter mitigado o seu prejuízo, assim como poderia o próprio juízo ter adotado outros meios suficientes para o cumprimento da obrigação, é razoável a redução da multa coercitiva para o montante final de $\mathrm{R} \$ 100.000,00$ (cem mil reais). [...] ${ }^{34}$

Destaca-se, por conseguinte, que muito embora não exista expressa previsão no Código de Processo Civil de 2015 que autorize a redução do valor da multa coercitiva em casos de conduta contrária à boa-fé por parte do credor, as recentíssimas decisões do Superior Tribunal de Justiça dão conta de que um novo panorama está sendo aplicado, no

\footnotetext{
${ }^{33}$ BRASIL. Superior Tribunal de Justiça. Acórdão de Agravo interno no Recurso Especial n 1478193/RN. Relator: SALOMÃO, Luis Felipe. Publicado no DJe 01/03/2017.

${ }^{34}$ BRASIL. Superior Tribunal de Justiça. Acórdão de Agravo interno no Recurso Especial $n^{\circ} 738.682 / \mathrm{RJ}$

Relatora: GALLOTTI, Maria Isabel. Publicado no DJe 14/12/2016.
} 
Revista Eletrônica de Direito Processual - REDP.

Rio de Janeiro. Ano 12. Volume 19. Número 2. Maio a Agosto de 2018

Periódico Quadrimestral da Pós-Graduação Stricto Sensu em Direito Processual da UERJ

Patrono: José Carlos Barbosa Moreira (in mem.). ISSN 1982-7636. pp. 67-83

www.redp.uerj.br

sentido de que as astreintes não podem servir para que o credor crie uma espécie de poupança diária, porém ao contrário, é dever do credor tomar todas as medidas necessárias e possíveis para que o prejuízo da outra parte não se agrave ainda mais em razão da sua inércia.

\section{CONCLUSÃO}

O princípio da boa-fé objetiva aplica-se ao direito processual civil brasileiro, estando inclusive positivado em vários artigos do Código de Processo Civil de 2015, destacando a norma que assegura que todos os participantes do processo devem se comportar de acordo com a boa-fé, ou seja, é necessário que as partes conduzam o processo em mais estrita lealdade, idoneidade, lisura e cooperação processual, evitando ao máximo que as suas condutas prejudiquem a outra parte.

Neste aspecto, considerando a aplicação do princípio da boa-fé processual, podese destacar neste âmbito a presença de alguns dos deveres anexos e secundários deste princípio norteador, tais como a supressio, venire contra factum proprium e o duty to mitigate the loss, institutos que no ordenamento jurídico pátrio foi recepcionado e fundamentam-se na boa-fé.

Especialmente com relação ao duty to mitigate, consistiu-se no dever de o credor mitigar o seu próprio prejuízo, em outras palavras, é a incumbência de não exacerbar o prejuízo do devedor, sendo perfeitamente aplicada no âmbito processual, em especial efeito às astreintes.

Não é raro verificar uma específica situação, na qual o credor de uma multa coercitiva se mantém inerte de forma proposital para que os valores da penalidade imposta pelo judiciário cheguem a níveis exorbitantes, a esse exemplo cita-se um clássico cenário em que o credor posterga o pedido de execução da multa apenas para majorá-la, o que por certo implicará em um valor muito maior ao inicialmente arbitrado, em verdadeiro prejuízo do devedor, demonstrando assim a violação ao princípio da boa-fé e verdadeiro abuso de direto do autor.

O contexto acima mencionado como exemplo, no entanto, não resume as inúmeras hipóteses em que pode ser visualizado o abuso do direito do credor e a violação da boa-fé processual, em especial quando o credor tinha reais condições de evitar o 
Revista Eletrônica de Direito Processual - REDP.

Rio de Janeiro. Ano 12. Volume 19. Número 2. Maio a Agosto de 2018

Periódico Quadrimestral da Pós-Graduação Stricto Sensu em Direito Processual da UERJ

Patrono: José Carlos Barbosa Moreira (in mem.). ISSN 1982-7636. pp. 67-83

www.redp.uerj.br

agravamento do seu próprio prejuízo, mas não atuou ou cooperou com o cumprimento da obrigação. Contudo, a respeito de tal situação, verifica-se que a lei processual pátria não prevê especificamente a possibilidade de redução ou extirpação da multa coercitiva para os casos em que houver violação ao duty to mitigate the loss, cabendo ao intérprete do direito demonstrar a sua possibilidade de aplicação.

Desta forma, considerando a manifesta positivação do princípio da boa-fé processual, com consequente aplicação de seus deveres colaterais e secundários, conclui-se que a referida teoria deve ser aplicada ao processo civil, especialmente para o fim de acolher as teses de redução da multa coercitiva sob os fundamentos do dever de mitigação do prejuízo, considerando que as partes no processo devem cooperar com o andamento processual, destacando assim a necessidade de uma conduta positiva por parte do credor em auxiliar para o cumprimento da obrigação judicial condicionada à multa coercitiva.

Inclusive, vale destacar que embora seja uma temática recente o Superior Tribunal de Justiça já vem aplicando este entendimento, qual seja, de ser totalmente possível a redução das astreintes com fundamento no dever do credor mitigar o seu prejuízo, entendimento este que objetiva coibir condutas ímprobas realizadas pelos litigantes no processo judicial, em verdadeira busca pela observância da boa-fé processual.

\section{REFERÊNCIAS BIBLIOGRÁFICAS:}

ASSIS, Araken. Processo civil brasileiro, volume I [livro eletrônico]: parte geral: fundamentos e distribuição de conflitos. 1 ed. São Paulo: Revista dos Tribunais, 2015.

BODIN DE MORAES, Maria Celina; BARBOSA, Fernanda Nunes. O processo civil constitucionalizado. Editorial à Civilistica.com. Rio de Janeiro, a. 5, n. 1, 2016. Disponível em: <http://civilistica.com/o-processo-civil-constitucionalizado/>. Data de acesso 07/11/2017.

BRASIL. Código Civil (2002). Lei no 10.406, de 10 de janeiro de 2002. Disponível em: <http://www.planalto.gov.br/ccivil_03/leis/2002/L10406.htm>. Acesso em: 23 out. 2017

BRASIL. Código de Processo Civil (2015). Lei $n^{\circ}$ 13.105, de 16 de março de 2015. Disponível em: <http://www.planalto.gov.br/ccivil_03/_ato20152018/2015/lei/113105.htm>. Acesso em: 23 out. 2017. 
Revista Eletrônica de Direito Processual - REDP.

Rio de Janeiro. Ano 12. Volume 19. Número 2. Maio a Agosto de 2018

Periódico Quadrimestral da Pós-Graduação Stricto Sensu em Direito Processual da UERJ

Patrono: José Carlos Barbosa Moreira (in mem.). ISSN 1982-7636. pp. 67-83

www.redp.uerj.br

BRASIL. Superior Tribunal de Justiça. Acórdão de Agravo interno no Recurso Especial nº

738.682/RJ Relatora: GALLOTTI, Maria Isabel. Publicado no DJe 14/12/2016.

BRASIL. Superior Tribunal de Justiça. Acórdão de Agravo interno no Recurso Especial $n^{\circ}$ 1478193/RN. Relator: SALOMÃO, Luis Felipe. Publicado no DJe 01/03/2017.

FRADERA, Vera Maria Jacob de. Justificativa a proposta de Enunciado: O credor poderá ser instado a mitigar o próprio prejuízo (art. 422). In: III Jornada de Direito Civil. Organização Ministro Ruy Rosado de Aguiar Júnior. Brasília: Conselho da Justiça Federal, Centro de Estudos Jurídicos, 2005. Disponível em: <http://www.cjf.jus.br/cjf/CEJ-Coedi/jornadas-

cej/III\%20JORNADA\%20DE\%20DIREITO\%20CIVIL.pdf/view> Acesso em 18/07/2017.

GOMES, Orlando. Contratos. Rio de Janeiro, Forense, 2009.

MARTINS-COSTA, Judith. A boa-fé no direito privado: critérios para a sua aplicação. São Paulo: Marcial Pons, 2015.

MARINONI, Luiz Guilherme. Novo curso de processo civil: teoria do processo civil, volume I. São Paulo: Revista dos Tribunais, 2015.

MEDINA, José Miguel Garcia. Novo Código de Processo Civil Comentado: com remissões e notas comparativas ao CPC/1973. 4ed. São Paulo: Revista dos Tribunais, 2016.

NEGREIROS, Teresa. O princípio da boa-fé contratual. In: BODIN DE MORAES, Maria Celina (Org.). Princípios do direito civil contemporâneo. Rio de Janeiro: Renovar, 2006. p.221-254.

NERY, Rosa Maria de Andrade. Instituições de direito Civil, volume I, tomo I: teoria geral do direito privado. São Paulo: Revista dos Tribunais, 2014.

TARTUCE, Flávio. Manual de direito civil: volume único. 6. ed. rev., atual. e ampl. Rio de Janeiro: Forense; São Paulo: Método, 2016.

THEODORO JUNIOR, Humberto. Curso de direito Processual Civil. Rio de Janeiro. Forense, 2005.

SCHREIBER, Anderson, A proibição de comportamento contraditório: tutela da confiança e venire contra factum proprium. 4. ed. revista e atualizada. São Paulo: Atlas, 2016.

VENOSA, Sílvio de Salvo. Direito civil: teoria geral das obrigações e teoria geral dos contratos. 13. ed. São Paulo: Atlas, 2013. 